Pre-Print

\title{
Social media objectives and challenges of law libraries: A systematic literature review
}

\begin{abstract}
:
The purpose of this paper is to examine the scholarly peer-reviewed publications relating to social media objectives and challenges of law libraries. The methodology is that of a systematic literature review. The studies included in this systematic literature review show that the social media objectives of law libraries are: promoting and marketing resources and services, supporting legal research teaching and tutorials, and providing reference services. Secondly, law libraries face some challenges with their social media usage regarding the quality and scope of content, technological difficulties, and online privacy.
\end{abstract}

Keywords: Social media; law libraries; systematic literature review

\section{INTRODUCTION}

Law libraries around the world have been using social media in various ways. Since social media allows law libraries to be closely connected with users in interactive online environment, social media helps law libraries to quickly share information with a wide network of people. Some law libraries are actually using the information that their users post and share on their social media to develop services and collections that tailor to the users' needs.

A study by Intahchomphoo (2013) $)^{1}$ presents an action research paper suggesting law libraries should use social media like YouTube for their virtual tours and online tutorials, especially academic law libraries. Furthermore, a study by Jeske et al $(2014)^{2}$ describes how law libraries can use social media as a marketing tool to promote upcoming legal database training sessions. What this paper found was that using Facebook as a promotional tool helped increase the registration numbers for legal database workshops at their law library. Information was rapidly shared among users through this platform and it increased the chances of locating people who were interested or were actually looking for these type of workshops but who were not being reached through traditional media like posters or radio announcements. However, law libraries also face some challenges with social media. According to Intahchomphoo et al (2016) ${ }^{3}$ research shows that the majority of law students - who participated in their e-learning research — do not wish to see social media functionalities being implemented in their law library's legal research website. The authors posit that law students think of social media as something to be used for personal socialization with their friends and not as something to be used in their academic online environments.

With the papers and case studies mentioned above, we can see that social media can be very useful and challenging at the same time for law libraries. Moreover, it might even be possible that law libraries use social media differently from other subject libraries such as health science, arts, or engineering. For this reason, we decided to conduct this systematic literature review in relation to 
the social media objectives and challenges for law libraries. We will be finding answers for this review by using scholarly peer-reviewed publications as the information source.

As a research methodology for this paper, we selected the systematic literature review method, for its transparent research approach. Each research step in a review has to be clearly identified and explained in order to limit personal bias over the selection of the included studies (Kitchenham et al, 2010 $)^{4}$. We aim to present credible findings that can be reproduced by anyone undertaking the same research steps.

In addition, we would like to clarify the difference between the term "social media" and the term "social networking." Both terms are often used interchangeably especially in the non-academic context, but in fact, social networking and social media have their own distinct meanings. Social media refers to Web 2.0 functionalities relating to user generated content (Obar \& Wildman, $2015)^{5}$, whereas social networking is more about how people use social media tools to communicate and engage with each other and build online communities (Subrahmanyam, Reich, Waechter, \& Espinoza, 2008) ${ }^{6}$. There are various types of social media including social networks, micro-blogging, online forums, online bookmarking, wikis, social news, and media sharing (Farzindar \& Inkpen, 2015) $)^{7}$. This research paper will primarily make use of the term "social media" as it better covers the research activities in this paper. But we will use both terminologies in our search strings to ensure that we do not miss important publications that are written with only one of those terminologies.

\section{REVIEW QUESTIONS}

This systematic literature review contains two research questions. They are:

- What are the social media objectives of law libraries?

The first research question seeks information about the objectives of social media usage by law libraries. This review includes all subcategories of law libraries, for example: academic law libraries, government law libraries, courthouse law libraries, law firm libraries, law association libraries, etc.

- What are the social media challenges of law libraries?

The second question looks at the challenges that law libraries are facing with their social media usage. All subcategories of law libraries will be included, as defined in the first research question. 


\section{REVIEW METHODS}

The following subsections present the review method components that are used in this paper. They include information about the data sources and search strategy, study selection criteria, and included and excluded studies.

\section{DATA SOURCES AND SEARCH STRATEGY}

Three academic databases were used to search for scholarly publications for this review: SCOPUS, Library and Information Science Source, and Academic Search Complete. The first author accessed the databases via the University of Ottawa Library (Canada). Both SCOPUS and Academic Search Complete house academic collections in many subject areas, whereas the Library and Information Science Source focuses solely on publications in the areas of Library Sciences and Information Studies. The variety of subject content in these repositories is important because we wish to retrieve information from interdisciplinary sources in order to find a variety of viewpoints. The included studies do not need to be written by librarians only, but can be works using science, social science, or business perspectives. The first author performed a full-text search in all three selected databases on the same day, July 6, 2016, with the same search strings (see Figure 1).

\section{("law library" OR "law libraries") AND ("social media" OR "social networking” OR} Facebook OR Twitter OR YouTube)

\section{Figure 1: Search Strings Designed for this Systematic Literature Review}

In this review, we chose to conduct a full-text search of each database. Pertinent results can be missed by a researcher if the chosen search terms do not appear in the title or abstract and they do not chose to do a full-text search.

The search terms were designed based on two main concepts. The first concept is about the terminology of law libraries in both single and plural nouns. They are linked with an "OR" Boolean operator. It allows for records that are found with either word. The terms "law library" and "law libraries" are placed within quotation marks for searching as an exact phrase. The second concept of search terms regards social media. Included are of the term social networking, as well as the names of popular social media tools like Facebook, Twitter, and YouTube, bearing in mind that these tools might be used in lieu of more general terms. Both the first and second concepts are connected with the "AND" Boolean operator to command the selected databases to bring results that contain both concepts for our initial selection. 


\section{STUDY SELECTION CRITERIA}

This review used the following criteria to select all primary studies in which to perform a content analysis towards finding answers to the review questions:

- Type of Publication: peer-reviewed journals and conference proceedings.

- Date of Publication: The included studies must have been published between January 2004 and June 2016. The date of publication limit is based on the fact that Twitter began operating in 2006, and Facebook in 2004. Twitter and Facebook are considered as the most commonly used international social media tools.

- Language: English.

- Subject: All academic disciplines.

\section{INCLUDED AND EXCLUDED STUDIES}

The second table below (Figure 2) summarizes the review method and the final number of studies included in this review. In the end, we found ninety-one papers matching the search criteria. The frequency of studies published during that period shown in the timeline (Figure 3) suggests that there was an increase in studies related to the use of social media by law libraries between 2006 and 2015 with some small drops in 2011, 2013, and 2014 during that timeframe. The year 2015 represents the peak of publications in this topic. After completing a review of all the retrieved studies, there are twenty studies in answer to our review questions.

\begin{tabular}{|l|c|c|}
\hline \multicolumn{1}{|c|}{ Data Sources } & $\begin{array}{c}\text { Number of Studies with } \\
\text { Search Strings }\end{array}$ & $\begin{array}{c}\text { Number of Studies Fitting } \\
\text { with Selection Criteria }\end{array}$ \\
\hline SCOPUS & 137 & 79 \\
(Searched on July $\left.6^{\text {th }}, 2016\right)$ & 56 & 12 \\
\hline $\begin{array}{l}\text { Library and Information } \\
\text { Science Source } \\
\text { (Searched on July } 6^{\text {th }} \text {, 2016) }\end{array}$ & 28 & $\begin{array}{l}\text { (6 duplications with SCOPUS } \\
\text { and not being counted) }\end{array}$ \\
\hline Academic Search Complete & & 0 \\
(Searched on July $\left.6^{\text {th }}, 2016\right)$ & & $\begin{array}{l}\text { (5 duplications with SCOPUS } \\
\text { and not being counted) }\end{array}$ \\
\hline Total & $\mathbf{2 2 1}$ & $\mathbf{9 1}$ \\
\hline
\end{tabular}

Figure 2: Studies Identified by the Search Strings and Selection Criteria 


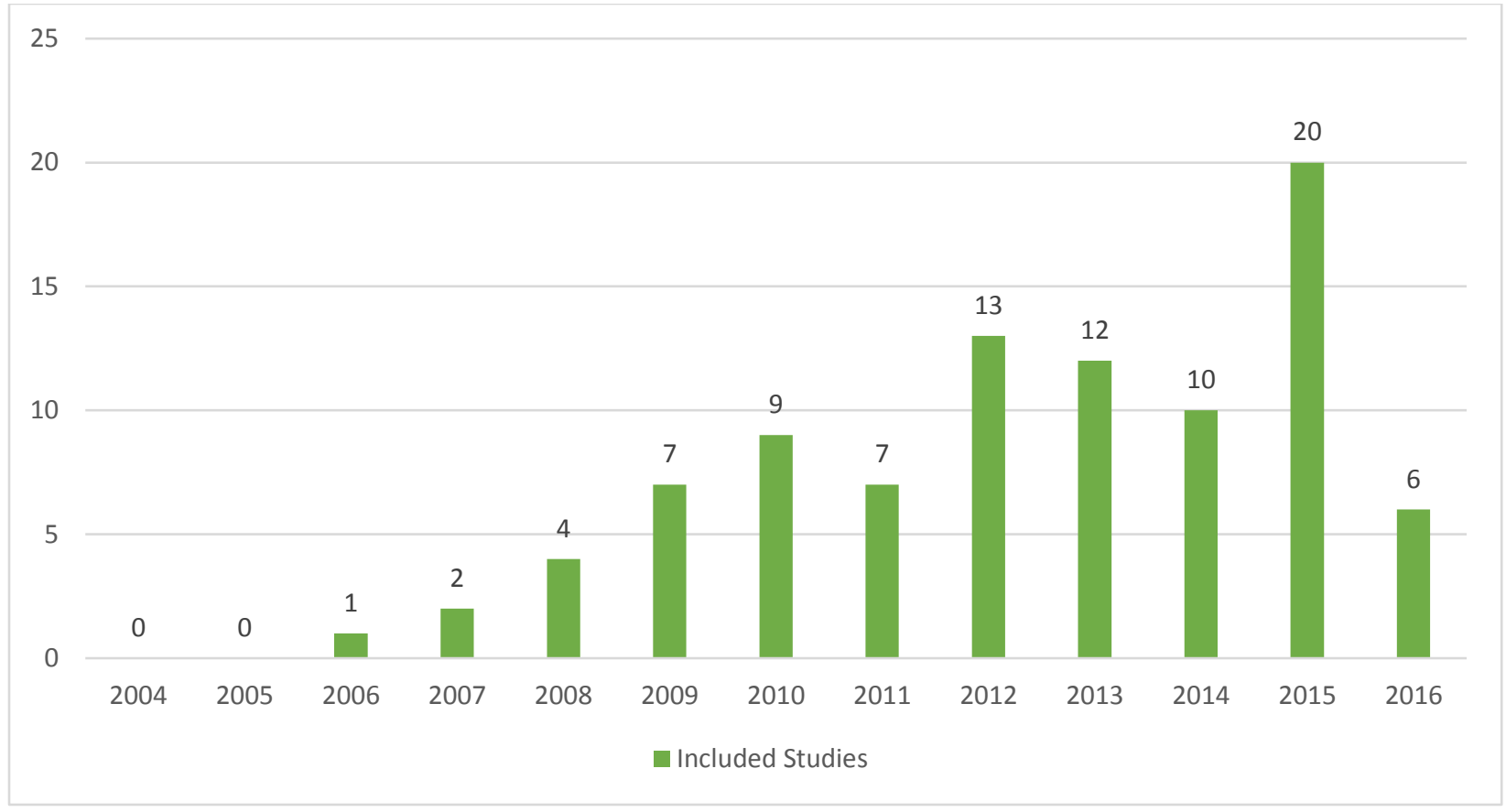

Figure 3: Publication Years Timeline of Included Studies

\section{RESUITS}

The following is the findings from the included studies in answer to the research questions in this review.

\section{SOCIAL MEDIA OBJECTIVES OF LAW LIBRARIES}

The included studies present information that law libraries are using social media mainly for the following objectives: promoting and marketing resources and services; supporting legal research teaching and tutorials; and providing reference services.

\section{- Promoting and Marketing Resources and Services}

Social media is a tool for law libraries to reach out to all type of users regardless of their professional titles and social status, since social media is already widely used across all population groups. Ax-Fultz (2015) and Bierman \& Valentino (2011) state that social media helps law libraries to better engage with users. Such engagement increases the value of law libraries in the users' viewpoints. Winter S. (2008) comments that many social media tools permit law libraries to communicate in real time with users in the forms of chatting or commenting on the online group discussions. Building closer community collaboration between law libraries and users via social 
media can be an advantage for law libraries, since it demonstrates the law library's value in an era of fast-changing technology (Davidson \& Matheson, 2008).

Many of the studies included in this review indicate that law libraries use social media especially in promoting and marketing their resources and services. An article by Dority Baker (2013) describes how academic law libraries can promote law professors and law librarians' research publications, as well as course materials, to law students through social media. Dority Baker (2013) also states that academic law libraries' social media postings should always refer to academic resources that are hosted in an open access format, such as institutional digital repository or Social Science Research Network (SSRN). Winter S. (2008) also supports open access publishing and suggests that law libraries should include links to their online catalogue and webpage in social media posts, being that it is a straightforward approach towards promoting law library services and collections. Davidson \& Matheson (2007) furthermore agree with this kind of approach and believe that social media expands access to information and discovery channels for users. Law library users can access the collections that law libraries house or subscribe to by finding out about these collections and subscriptions through the law library's social media accounts. Additionally, Steele \& Greenlee (2011) advise that law librarians should use blogging as a way to share lawrelated information with users. A good example is provided from the University of Pennsylvania Biddle Law Library in the USA. There, law librarians started blogging in 2007 to share information about their book reviews, reviews of web sites, databases and other e-resources, local special collections and archives, details about behind the scenes of law library operations, new exhibitions and special events, academic matters related to law students, and legal research tips. Similarly, Guo \& Huang (2013) also recommend that law libraries use blogging to promote their core services, such as collection development policy, reference services, promotion of law library events, book reviews and so on.

Another interesting concept found in the included studies regards using social media to promote law library initiatives and projects. Bierman \& Valentino (2011) mention law libraries' podcast initiatives. Danner, Leong \& Miller (2011) also refer to social media as a tool to broadcast new initiatives and policies of law libraries. They explain that in 2008, the law library directors from prestigious U.S. law schools got together to draft and sign on to "the Durham Statement on Open Access to Legal Scholarship". The group used a Wikipedia entry specifically to discuss the statement and to show the public that their law libraries are demanding open access to law school published journals for the public good. Moreover, Gragg \& Sellers (2010) support the same idea of law librarians using social media for their initiatives and projects - in their case Twitter-to update other people on what projects law libraries are working on at the moment and also to learn what topics other law librarians are interested in or working on.

McLaughlin (2015) found out that some academic law libraries use social media to gather feedback and input from law students and public users for collection development purposes. Considering the financial restraint many libraries find themselves in these days, this use of social media can be very beneficial in ensuring their resources truly reflect the needs of their users. Social media in this case becomes a tool to gather information used to help efficiently manage the limited collection budget of law libraries. 
Furthermore, there are some included studies that discuss social media as a tool for law libraries to perform unique tasks in promoting and marketing resources and services. For examples, the study by Keele \& Pearse (2012) focuses on social media and its roles in promoting content of published legal journals. Jayasuriya \& Brillantine's (2007) paper proposes the idea of using social media to create virtual law library tours. Han \& Hall (2012) put forward ideas of embedding multimedia, RSS feeds, Twitter, Facebook, etc. into LibGuides as a means of quickly updating users to changing information. Finally, blogs are used by some law firm libraries to advertise the firm to the public as the expert in their specific areas of law in order to attract more clients and recruit talented staff (Winter, 2008).

\section{- Supporting Legal Research Teaching and Tutorials}

Teaching is an essential task that almost every law library has to offer to their users, particularly law school libraries. Academic librarians often have to teach law students the principal of legal research beyond their day-to-day operations. Due to the fact that new generations (e.g. millennials) of law students have grown up constantly engaging with new technology, social media plays a big part of their lives. It makes sense then that law libraries should use social media to engage with their law students. Social media can supplement face-to-face legal research instruction by law librarians (Herrick \& Burriesci, 2009). A study by McLaughlin (2015) discussed how academic law librarians use social media to teach law students about legal research skill development, particularly about how to build research questions and find relevant materials both print and electronic resources.

Jayasuriya \& Brillantine (2007) discuss the important role of social media particularly in assisting law librarians with their legal research tutorials. In this situation, social media aids in building interactive learning tutorials, increasing visual engagement with graphics, audio, and video (multimedia). Law students can learn by listening or watching the tutorials videos. Jayasuriya \& Brillantine (2007) believe that social media encourages law students to have academic discussions as collective learning outside of the classroom. Correspondingly, the paper by Guyer (2013) mentions the use of social media by law libraries in legal research classes that are taught by law librarians. This paper is based on a case study at the Law Library of the University of Southern California Gould School Law. Law Librarians at this school introduced law students to new concepts in legal education using a problem/client-based learning method. Students were required to work with other learners during their legal research activities to solve a given legal issue. This method is referred to as "experiential learning". In their case study, social media was used as a tool for law students to collaborate among their groups when trying to complete their assignments.

\section{- Providing Reference Services}

Winter (2008) and McLaughlin (2015) describe how law libraries' social media can provide effective virtual reference services to users. Law libraries can use social media to reach out to users and educate people on what resources law libraries have to offer and how to access them. Social media is the quickest and most effective way to communicate between law libraries and users. It helps law libraries to have more channels to engage with users and it is considered as a low-cost mass communication approach. Davidson \& Matheson (2008) recommend that law libraries create 
webpages like Wikipedia, providing instructions on how to conduct legal research and how to search for those materials on their law library websites or in the physical law library spaces. This will allow users to study information on the law library Wiki on their own during their preferred hours. Law libraries have limited opening hours, but the same restrictions do not apply to the online blog and Wikis. In addition, social media is also good for law library staff to help them better perform reference services. Jackson's (2010) paper confirms that the Oklahoma City University Law Library's circulation and reference departments use Ning, a social media platform, to communicate and share documents, especially frequently asked questions, to help all new and experienced unit members to better provide answers during their reference service shifts. Winter (2008)'s study provides very good information in this area but focusing on law firm libraries. They use blogs as a way to share information internally among the library, lawyers' assistants, and lawyer teams in the law firm, which often are in different working locations and teams. Blogs can help to reduce the number of email communications as the law firm common information is already on social media. However, many law firm libraries' social media are strictly for the internal usage only. The general public would not able to see their contents in social media, which is opposite to the approach of many academic law libraries.

\section{SOCIAL MEDIA CHALLENGES OF LAW LIBRARIES}

The included studies show that there are three categories of social media challenges that law libraries are facing. They are: the quality and scope of content; technological difficulties; and online privacy.

\section{- Quality and Scope of Content}

Social media adaptation among law libraries face some challenges related to content creation. AxFultz (2015) and Winter (2008) report it is not always easy for law libraries to come up with good content and strategies to use in their social media in order to reach the targeted users. It is possible that some targeted users might not use social media at all or not the same ones that law libraries are using. In this situation, law libraries have to think of the financial and associated impacts of ineffective social media implementation (Winter, 2008).

The papers by Steele \& Greenlee (2011) and Guo \& Huang (2013) discuss the challenges in writing law library blogs. They think that blogging has to maintain some level of professionalism, not too formal or informal. Law library blogs should stay in the middle tone in order to make their blogs interesting, but at the same time, maintaining a good professional level. Additionally, Jayasuriya \& Brillantine (2007) and Davidson \& Matheson (2007) compare the user-built folksonomies vs. the expert-built taxonomies in social media. The social media functionality allows anyone to create subject headings freely. It raises some concerns about the accuracy and consistency of those tags or subject headings, especially, when it deals with legal or academic materials that should have experts in the subject areas catalogue or tag all metadata related to the items as it is not easy for just anyone to do it accurately. 
Furthermore, Davidson \& Matheson (2008) point out a very good point concerning law libraries' use of social media and copyright. They are concerned about the copyright status of information that law libraries share on social media. That information should be totally free from any copyright protection to avoid any legal responsibility that law libraries might have to deal with in the future. The authors suggest that law libraries should form some guidelines or best practices to handle the unexpected situations related to the copyright issues on law libraries' social media programs by appointing the contact person or working group who will deal specifically with such enquiries.

Finally, McLaughlin (2015) points out difficulties related to law librarians' professional rules and codes of ethics when it comes to the unauthorized practice of law. During reference services, law librarians are allowed to teach users how to find legal information, but are not permitted to give legal advice. If law librarians engage in the unauthorized practice of law, they can face criminal changes and claims for damages from law library users (malpractice). This scenario applies to law librarians who hold a law license. It has to be a totally lawyer-client professional setting or relationship. Therefore, it is necessary that law librarian's social media posts must not go over the limit of authorized practice of law.

\section{- Technological Difficulties}

The included primary studies mostly mention minor technological difficulties regarding the use of social media by law libraries. First of all, Herrick \& Burriesci (2009) outline the challenges with technological issues that have occurred with law libraries' online tutorials. The tutorials with social media functionalities constantly need to be updated as legal databases are continually changing their interface, information, and URLs. Herrick \& Burriesci (2009) also critique law library Wikis. As it turns out, sometimes Wikis are not very easy to edit. Even though a Wiki generally does not require knowledge of computer language such as HTML to edit a page, some Wiki tasks and platforms require users to know how to use computer markup languages to edit or modify their inputs. Furthermore, Gragg \& Sellers (2010)'s paper state that Twitter's 140 character limit makes it very difficult for law librarians to use the tool for comprehensive legal or research dialogue. As well, notifications in Twitter are programmed to show up on someone's pages. Law Libraries do not have much power over how their tweets will display on other users' screens.

\section{- Online Privacy}

Herrick \& Burriesci (2009) and Winter (2008) are worried about the online privacy issues related to the use of social media by law libraries. The paper by Herrick \& Burriesci (2009) explains how these concerns particularly apply to academic law libraries. When law librarians and law students connect on Facebook, even if they aim to join a Facebook page for academic purposes, both sides can see personal information of one another. Besides, McLaughlin (2015) notes that when law librarians post something on social media, they have to respect users' personal information and privacy. This practice involves personal and professional ethics, as social media are not technological tools that always protect peoples' personal information and privacy. Law librarians have to keep their user information confidential, even if they do not intend to infringe on anyone online privacy. 
Another very interesting point is found in Carter's (2014) study regarding unequal social media usage permission between law firm librarians and academic law librarians. Law Librarians in many law firms do not allow the use of social media or creation of social media accounts for their work. This policy is unusual among academic law librarians who are allowed and in fact are encouraged to use social media like Facebook, Twitter, and YouTube for their legal research tutorials or to promote the services of their law libraries. Understandably, law firms have to protect their own business information and their clients' privacy, which extends to the use of social media by the law firm librarians as well. This is to prevent any consequences that can damage reputation or financial gain of the law firms.

\section{DISCUSSION \& CONCLUSION}

This review presents findings that we have expected, and also uncover some unexpected results. The objectives of social media usage among law libraries is connected to the core elements of law libraries' operations and services which are about providing access to resources and services, offering training and workshops, and answering or guiding the users' questions and requests. This review proves that social media has a good role in supporting activities and operations of law libraries. It is not surprising that the use of social media by law libraries in this review are about promoting and marketing resources and services, supporting legal research teaching and tutorials, and providing reference services.

Regarding social media challenges, we were expecting to see more studies about the concerns and challenges on users' online privacy and personal information. The included studies indicated that most social media challenges in law libraries are about the quality and scope of content. Several studies discussed how difficult it is to make law libraries' social media content and scope attractive enough to capture their users' attentions. About technological difficulty results in this review, there are not too many studies that are worried about system operational challenges. We think that as social media technologies have been developing so much and so fast, end-user interaction with the system has been relatively uncomplicated.

Future research in social media and law libraries should focus on how to help law libraries to create good quality social media content to attract users to engage and participate in the law library social media campaigns. Social media can help to inform the users' demographics. The user study via social media is another area that should be further explored.

In conclusion, we think this review reports the objectives and challenges of social media usage in law libraries with examples and details that come precisely from law libraries and law librarians. We hope this review will be beneficial to people who are conducting research in the use of social media by law librarians or anyone who is trying to improve their social media campaigns in order to enable their law libraries to better serve their users. 


\author{
Footnotes: \\ ${ }^{1}$ Channarong Intahchomphoo, "Law Library Virtual Tours and Tutorials on YouTube: The \\ Social Media Review” (2013) 38:1 Can L Libr Rev 22. \\ ${ }^{2}$ Margo Jeske et al, "Using Social Media, Apps, and Traditional Channels to Promote Legal \\ Databases Training: A Case Study of Social Marketing” (2014) 39:2 Can L Libr Rev 17. \\ ${ }^{3}$ Channarong Intahchomphoo et al, "Law Student Views on the Principles of Legal Research \\ Website: A User Experience Study" (2016) 16:3 Leg Info Mgmt 187. \\ ${ }^{4}$ Barbara A. Kitchenham et al, "Refining the Systematic Literature Review Process: Two \\ Participant-Observer Case Studies" (2010) 15:6 Empirical Software Engineering 618. \\ ${ }^{5}$ Jonathan A. Obar \& Steve Wildman, "Social Media Definition and the Governance \\ Challenge: An Introduction to the Special Issue" (2015) 39:9 Telecommunications Policy 745. \\ ${ }^{6}$ Kaveri Subrahmanyam et al, "Online and Offline Social Networks: Use of Social \\ Networking Sites by Emerging Adults” (2008) 29:6 Journal of Applied Developmental \\ Psychology 420. \\ ${ }^{7}$ Atefeh Farzindar \& Diana Inkpen, Natural Language Processing for Social Media, (San \\ Rafael, California: Morgan \& Claypool, 2015).
}

\title{
Included Studies Responding to the Review Questions:
}

Benjamin J. Keele \& Michelle Pearse, "How Librarians Can help Improve Law Journal Publishing" (2012) 104:3 Law Libr J 383.

Cindy Guyer, "Experiential Learning: Context and Connections for Legal Research: A Case Study" (2013) 32:3 Leg Ref Serv Q 161.

Darla W. Jackson, "Collaboration Versus Communication: Selecting the Appropriate Tool" (2010) 102:2 Law Libr J 315.

H. Kumar Percy Jayasuriya \& Frances M. Brillantine, "Student Services in the 21st Century: Evolution and Innovation in Discovering Student Needs, Teaching Information Literacy, and Designing Library 2.0-Based Services” (2007) 26:1-2 Leg Ref Serv Q 135.

Jackie Druery, Nancy McCormack \& Sharon Murphy, "Are Best Practices Really Best?: A Review of the Best Practices Literature in Library and Information Studies" (2013) 8:4 Evidence Based Library \& Information Practice 110.

James Bierman \& Maura L. Valentino, "Podcasting Initiatives in American Research Libraries" (2011) 29:2 Library Hi Tech 349. 
Jinchi Guo \& Jie Huang, "Making Microblog an Efficient Tool for Library Services: A Case Study" (2013) 63:2 Libri 87.

Jordon Steele \& Ed Greenlee, "Thinking, Writing, Sharing, Blogging: Lessons Learned from Implementing a Law Library Blog" (2011) 103:1 Law Libr J 113.

Katie Carter, "Same Same But Different" (2014) CILIP Update with Gazette 23.

Laura J. Ax-Fultz, "Igniting the Conversation: Embracing Legal Literacy as the Heart of the profession” (2015) 107:3 Law Libr J 421.

Marcia L. Dority Baker, "Using Buttons to Better Manage Online Presence: How One Academic Institution Harnessed the Power of Flair" (2013) 7:3 J Web Librarianship 322.

Ning Han \& Susan L. Hall, "Think Globally! Enhancing the International Student Experience with LibGuides" (2012) 24:4 J Electronic Resources Librarianship 288.

Paul Jerome McLaughin, "Wanting to Do More but Bound to Do Less: A Law Librarian's Dilemma" (2015) 56:2 Reference Librarian 119.

Phillip Gragg \& Christine L. Sellers, “Twitter” (2010) 102:2 Law Libr J 325.

Richard A. Danner, Kelly Leong \& Wayne V. Miller, “The Durham Statement Two Years Later: Open Access in the Law School Journal Environment" (2011) 103:1 Law Libr J 39.

Stephanie Davidson \& Scott Matheson, "Innovations in Providing Access to Research and Knowledge: Directions for Systems Improvement in the Law Library" (2008) 27:2-3 Leg Ref Serv Q 137.

Stephanie Davidson \& Scott Matheson, "The Evolution of Providing Access to Information: The Fall of the Online Catalog" (2007) 26:1-2 Leg Ref Serv Q 57.

Stephen Weiter, "Who's Really Computer Savvy? Web 2.0 Technologies and Your Library" (2008) 8:4 Leg Info Mgmt 270.

Susan Herrick \& Sara Kelly Burriesci, "Teaching Legal Research Online” (2009) 28:3-4 Leg Ref Serv Q 239.

Susanna Winter, "Law Firm Libraries in the 21st Century" (2008) 8:1 Leg Info Mgmt 28. 


\section{Biographies:}

Mr. Channarong Intahchomphoo (MIS, PhD Candidate in Electronic Business), Computer Reference Technician, Brian Dickson Law Library, University of Ottawa.

Channarong Intahchomphoo holds a bachelor's degree (Chiang Mai University, Thailand) and an English/French bilingual master's degree (University of Ottawa, Canada) both in Information Studies. His fields of research and current projects are: technology and indigenous peoples in Canada \& marginalized populations worldwide, social computing, data/text mining for risk monitoring and response applications, human-computer interaction and UX, economics and computation, and innovative technology for libraries. He is also pursuing a doctorate in EBusiness with the research topic of "Facebook and Urban Indigenous Youth at Risk in Ontario: A Social Computing Research" at the University of Ottawa.

Ms. Margo Jeske (MLS), Director, Brian Dickson Law Library, University of Ottawa.

Margo Jeske has a bachelor's degree in French translation (Queen's University) and a master's degree in Library Science (Western University). She worked for several years in federal government departments and agencies and at the Library of Parliament, before joining the Brian Dickson Law Library, University of Ottawa as the Library Director. Margo is an active member of the Canadian Association of Law Libraries (CALL) and sits on the Law Libraries Section of the International Federation of Library Associations (IFLA).

Ms. Emily Landriault (MIS), Law Librarian, Brian Dickson Law Library, University of Ottawa.

Emily Landriault holds a bachelor's degree in English (University of Guelph) and a master's degree in Library Studies (Dalhousie University). She has worked at legislative libraries, with time spent both at the Library of Parliament and at the Ontario Legislature. She came to the University of Ottawa as a reference librarian at the Brian Dickson Law Library and recently moved into a position as the Copyright Services Librarian for the university. Emily is an active member of the Canadian Association of Law Libraries (CALL) and serves as the treasurer for the National Capital Association of Law Librarians (NCALL). 